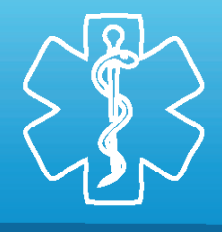

HISTORY OF MEDICNNE AND PHARMACY

Department of Oral and Maxillofacial Surgery, Iuliu Hatieganu University of Medicine and Pharmacy, Cluj-Napoca, Romania
DOI: $10.15386 / \mathrm{mpr}-1220$

Manuscript received: 29.10 .2018

Received in revised form: 28.11.2018 Accepted: 11.12.2018

Address for correspondence: hrotaru@yahoo.com

\title{
Prof. Dr. Gheorghe Bilaşcu. Pro patria
}

Alexandru Rotaru, Horatiu Rotaru

\begin{abstract}
Gheorghe Bilaşcu came to Cluj from Budapest, where he enjoyed all the privileges reserved for the high-class people in the Hungarian capital city, in 1919. He renounced this comfortable existence in order to establish the Romanian Dental Education in Cluj. When he made this choice, he was aware that he would sacrifice his life for a national ideal.

The following text describes the background and events that shaped the future of Romanian dentistry in Cluj, driven by the personality of Gheorghe Bilașcu.
\end{abstract}

Keywords: Gheorghe Bilașcu, Romanian dentistry, history of dentistry

When the history of science and medical art is written with a critical outlook, the chapter dedicated to "Dentistry Education in Romania" will begin with the name of Gheorghe Bilaşcu (Figure 1). This was one of the conclusions that, 92 years ago, the renowned historiographer of medicine, Valeriu Lucian Bologa, pronounced about Gheorghe Bilaşcu [1]. When he drew this conclusion, the author relied on the fact that, in only a few years, maybe the most important years of Romania, Dr. Bilaşcu, through his deeds, left a mark in history. It was a short period of only seven years, but a very fruitful one, which can be expressed in three famous words, quoting Caesar's message to Rome, after his swift victory in Zala (47 BC), over France, king of Pontus: "veni, vidi, vici".

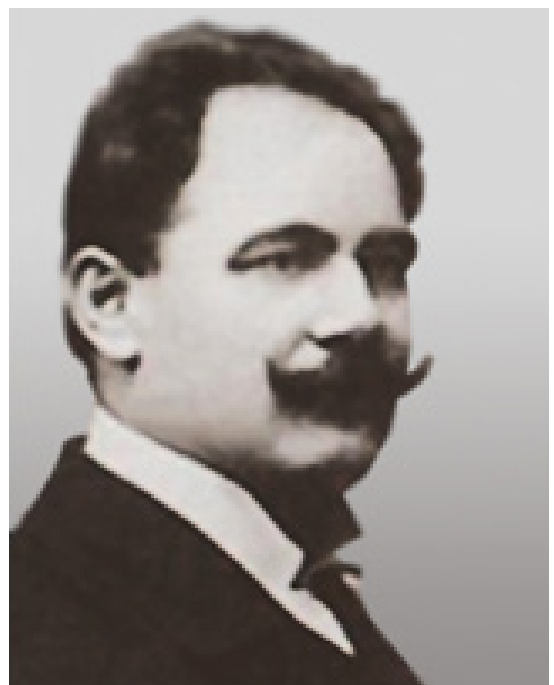

Figure 1. Prof. Dr. Gheorghe Bilașcu.
Keeping the proportions, the same may be said about Gheorghe Bilaşcu, who, within such a short period of time, changed the history of Romanian dentistry. He came to Cluj in 1919, saw the situation of Dentistry as a branch of Medicine and as a science, and removed all the obstacles preventing its recognition and affirmation as a medical branch and as an academic profession.

Dr. Gheorghe Bilaşcu came to Cluj from Budapest, where he enjoyed all the privileges offered by the great tycoons, bankers and the high class of the Hungarian capital [2]. He gave up all this in order to establish the Romanian Dental Education in Cluj. When he made this choice, he was aware that he would sacrifice his life for a national ideal. His dedication and spirit of sacrifice for the national ideal came from the family history, from his forefathers originating in the region of Maramureș, deeply connected to the history of the Romanians. His father, Gheorghe Bilaşcu, also known by the name of Lupşac, worked as a member of the Noble Petrova Ownership Organization. His mother, Maria, (born Mihalca, also known as Onciul), just like his father, was from a family with ancient historical origins.

$\mathrm{He}$ attended the lower secondary education at the "Piarists' Parents High School" in Sighetu Marmaţiei, where they also enrolled Romanian students of Greek Catholic confession. Romanian religion and language were taught by Romanian priests. Further on, he finished High 
School and graduated from the Reformed High School in the same city, where, during the entire period, he was the best student, graduating "Magna cum Laudae" [3].

He studied in Budapest, starting with the Faculty of Law, under the pressure of his parents, but which he abandoned in favor of the Faculty of Medicine, which corresponded better to his psychological, moral and social profile.

From then on, his concerns outweighed the strictly individual interests in Budapest, joining the work of the Romanian students of Transylvania and Banat who fought for national emancipation. It was a difficult time for the Romanians in Maramures, Transylvania and Banat, who were subjected to severe restrictions and denationalization. The Appony Law, designed for this purpose, was one of the most unfair laws of the time. In such conditions, it was natural that the tendency of the Romanian youths enlightened in the Austro-Hungarian Empire was to seek a form of resistance. And there was no better way than emancipation through culture. The Literary Society "Petru Maior" in Budapest, where Gheorghe Bilaşcu held various positions, was the one that promoted emancipation [4].

After graduating from the Faculty of Medicine and after having created a name among the professionals in the metropolis, his material situation became prosperous, which enabled him to contribute to the moral and material support of the mentioned cultural society. Since then, his home in Budapest became a meeting place for the young Romanians who were part of the "Petru Maior" Literary Society.

In this context, it is worth mentioning that its members also kept in touch with the "Romania Juna" Association in Vienna, which functioned in the period 1871-1919 and had the same goals. The objectives of both societies were, besides the resistance to denationalization, the preservation and development of the Romanian language and culture and the creation of Romanian academic institutions. This idea never left Gheorghe Bilaşcu. This is also explained by the fact that when, after 1918, the Congressional Council invited him to initiate the Dental Education in Cluj, he accepted, knowing that he would change his privileges for deprivation, as it will later prove to be true.

Dr. Bilaşcu's belief in the school's enlightening role, doubled by an unparalleled generosity, noticed by all those who lived around him, determined him to support, at his own expense, the education of children from his native village, in various schools and crafts. But he went even further and, over time, he expanded further. Although his actions did not reach the high level of the great lawyer Emanuel Gojdu, they have - nevertheless - reached levels worthy of being recorded in history. It is enough to recall the scholarships he gave from his own incomes to young students from the region of Maramures at the University of Budapest, especially at the Faculty of Medicine. Among them are Alexandru Belin and Gheorghe Bârlea, who graduated from the faculty in 1892 , the latter becoming a true apostle of the specialty and worthy collaborator of the Professor at the Department of Dentistry and Dentistry of the Upper Dacia University of Cluj (Figure 2).

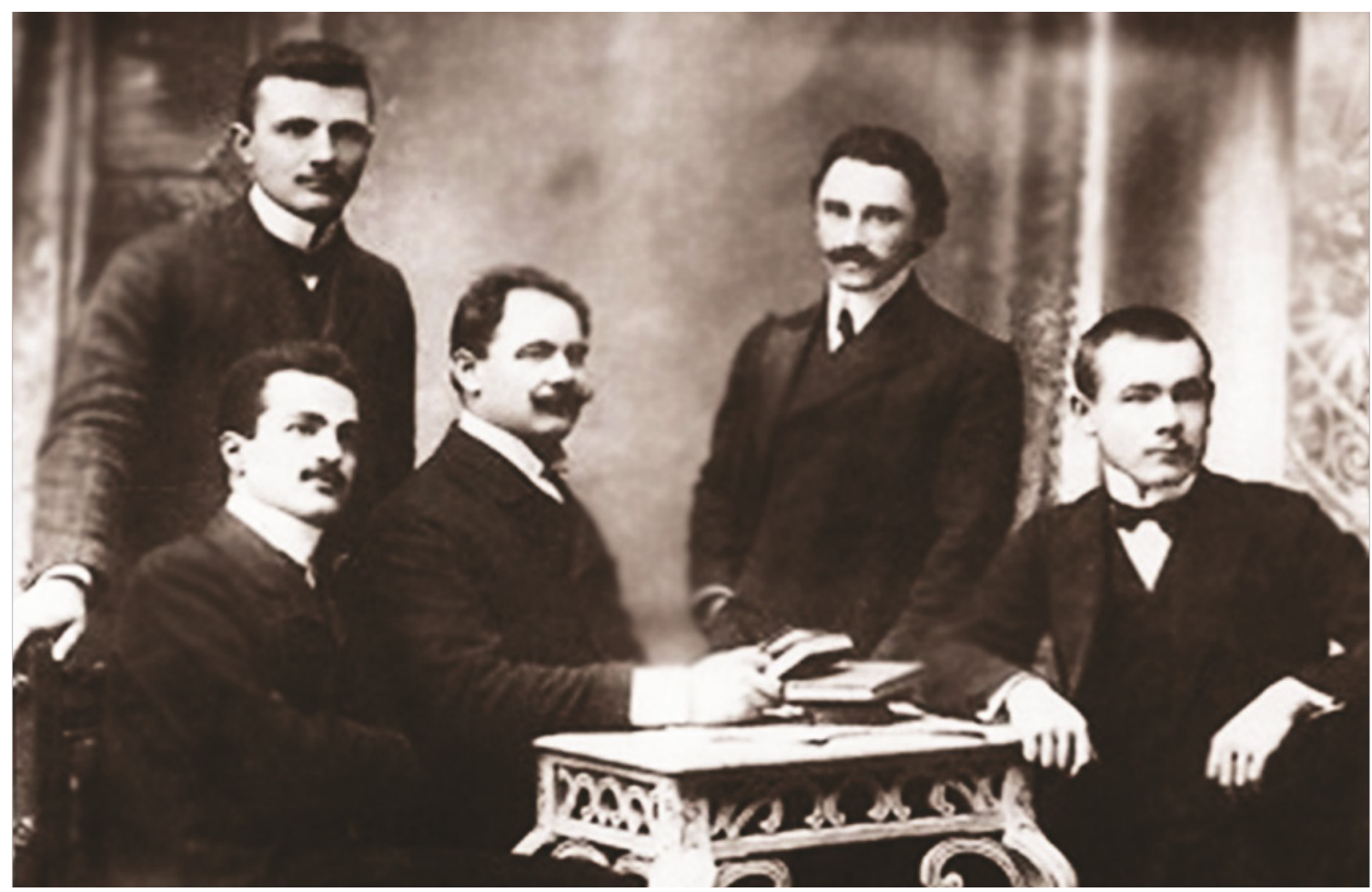

Figure 2. Gheorghe Bilaşcu (center), at the table with the young men, which he supported through their studies in Budapest. To his left, standing, Gheorghe Bârlea. 
Referring to Prof. Bilaşcu, V.L. Bologa recorded in his book, "Sentimental Reminders": "His goodness was experienced by countless sons of no one, who, frightened by the unfamiliar Budapest, came to him to find support and counsel. Neither parted with him with a naked soul nor empty handed " [5].

It should be noted that, at that time, the Romanian National Party, which functioned in the Parliament of Budapest, had adopted a strategy of political passivity, which the "young steel men" later, headed by Goga and Tăslăuanu, considered to be damaging to the interests of the Romanian population. Under those circumstances, the only ones fighting for national rights were the cultural societies mentioned above, of young people studying in the Hungarian capital. They were joined by the "Lupta" [Fight] magazine, in which student Onisifor Ghibu and Dr. Gheorghe Bilaşcu were actively involved, personalities who would become founders of the University of Dacia Superior in Cluj (Figure 3) [6].

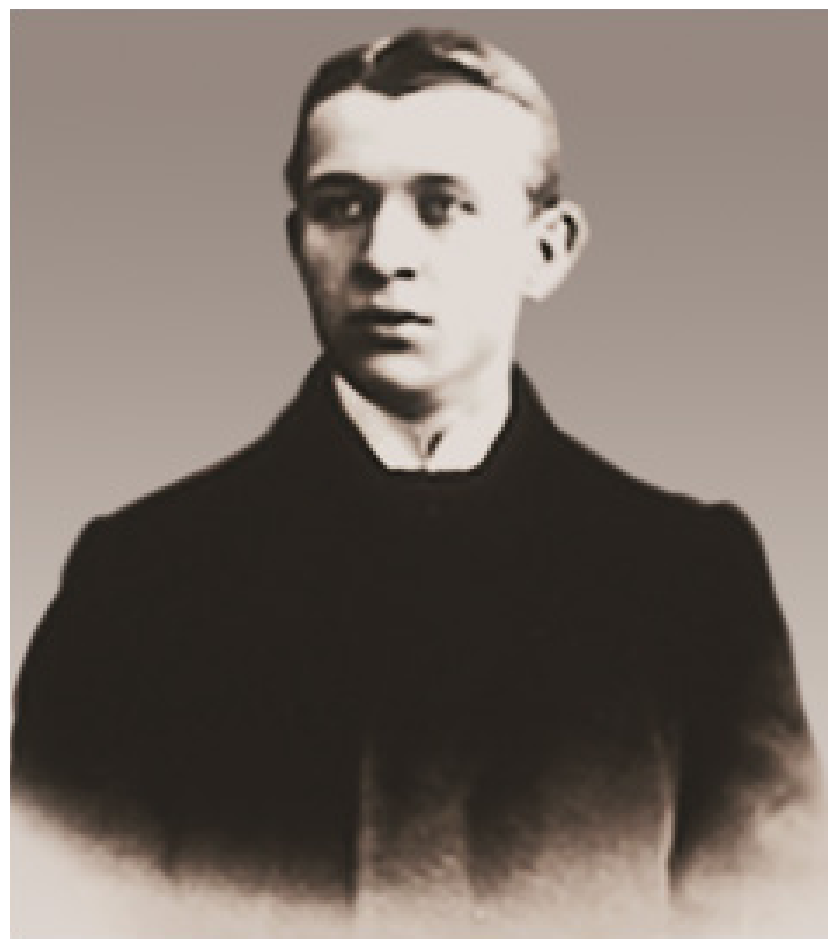

Figure 3. Onisifor Ghibu, student in Budapest and editor of "Lupta" magazine.

The persecutions to which the Romanians from Transylvania and Banat were subjected, as well as the danger of denationalization, which intensified from one year to the next, and at the same time the professional popularity he enjoyed in the Hungarian capital and the feeling of belonging to the Romanian nation, determined Dr. Bilaşcu to assume a political responsibility in the Hungarian Parliament. For the same reason, he decided to run in the 1906 elections for a deputy seat in the Chamber of Deputies, as an independent, in the Viseu constituency. The Romanian patriotism in this period began to revive, as did the activity of the Romanian National Party. But to the same extent, the aggression of the Hungarian State against the Romanians in Transylvania and Banat reached unusual levels, in order to prevent their participation in the elections. On the other hand, the Romanians were fed false promises with the aim of influencing their voting options in favor of the Hungarian Members.

From the Hungarian ruling party, along with Bilaşcu, the Hungarian state secretary, Nagy Ferenc, had run for the same electoral constituency. A few days before the elections, the Romanian communes around Vișeu were occupied by Hungarian Gendarmerie troops. Arrests were made and steps were taken to prevent Romanians from accessing the Vișeu polling station. The prospect of collisions between the Romanian population and the gendarmes was inevitable. Therefore, in order to avoid bloodshed, Dr. Gheorghe Bilaşcu, a peaceful man, withdrew his candidacy in the last days of the elections. Under these circumstances, the Romanian population did not participate in the elections. The same thing happened in Beiuss and other areas of Transylvania, where the conflict between the Romanian population and the gendarmerie became a tragic reality.

His Romanian patriotic sense and his feeling of belonging to the nation was proved by two gestures: his will of 1915 and repatriation in 1919.

At that time, the testament was a legal act of great civic courage, as it added to the support of the Romanian youth, just when the Apony Law exerted its effects on the Transylvanians and when the Romanian language education in Maramureș, Transylvania and Banat was on its way to be eradicated. Dr. Bilaşcu thought to donate his fortune to his compatriots eager to learn, aware that only by education and culture, the people to whom they belong would rise and make known their value, in the same way he did. On December 12, 1915, in the presence of Bishop Vasile Hossu, Bilaşcu gave a human and patriotic perspective to his wealth before leaving for the Italian front.

The content of the testament is known from various sources, by all those who have studied the biography of the great physician and professor. It is also worth mentioning here: "I leave all my mobile and immovable property to the Venerated Capitlu of Alba Iulia and Fagaras in Blaj for the support of a confessional school with Romanian as a teaching language in my native village Petrova and for scholarships for the young people with no material means, for them to pursue any kind of career. It is advisable to give these funds to sons of peasants, because they are the healthy social category and the unspoiled spring from which, in time, must rise the glory and power of the Romanian people. The first condition to have access to the funds of my foundations is to be a young Romanian with a good attitude, having all the signs that he will become a keen man and with a strong character, because we, the Romanians, have a lack of men with noble heart and reliable character." [7]. 
Soon came the moment of the liberation of Transylvania, Maramures and Banat, which for the Romanians in these provinces meant access to education and culture in the national language. In 1919, the Council, a kind of Provisional Government, based in Sibiu, knew very well the socio-cultural status of the liberated provinces. One of the most important issues facing this Council was the education and culture of the Romanians, which could be built only through schools and universities. The University of Cluj was one of the major objectives that was expected to accomplish many ideals. In the composition of the Council were personalities who knew how to make a perfect selection of the teaching staff and which aimed to lay the foundations of the Romanian University in Cluj.

Among those selected for the Faculty of Medicine of the new university was Dr. Gheorghe Bilaşcu, Romanian doctor from Maramureş, known and appreciated as one of the most valuable doctors of Hungary. He was entrusted with the task of establishing the University of Dentistry, which was previously lacking even in the Hungarian University of Cluj. This will secure him a well-deserved place in history, along with Dr. Cihac, Turnescu, Herãscu or even Davila and Babes, as appreciated by the famous Historiographer of Medicine Prof. Valeriu Lucian Bologa [1].

The national dimension of his work is also due to the fact that he did not limit himself to laying only in Cluj the foundations of a Department of Dentistry within the Faculty of Medicine in Romania, but struggled with the state authorities and even the university ones, for such departments to be established at the faculties of Bucharest and Iasi. The reason was one of national interest, the population of Romania being almost totally devoid of dental practitioners [8,9]. Only one faculty, like the one in Cluj, could not have met this objective. In order to achieve this aim, not only ignorance, but also the bad faith of decision-makers, both at university level and especially from the Ministries of Education and Health, had to be defeated. In this struggle, Dr. Bilaşcu joined three valuable doctors from Bucharest: D. D. Niculescu, C. Dimitrescu and C. Constantinescu.

Taking as arguments the dental needs of the population and the precedent from Cluj, Prof. Bilaşcu and the three personalities from Bucharest, exerted pressure on the authorities, to decide the extension of the dental education in Bucharest and Iasi. Due to the unwillingness of the officials, this aim was reached in Cluj only after 10 years, and in Iasi, much later, even though Dr. Macarovici was fighting for it.

Besides the foundation of the Higher Dental Education and the provision of the dental sanitary network with specialists trained in Romania, Prof. Bilaşcu also had the third problem that was the most difficult to solve. It was about purging the dental health care network from those who acted like parasites of the specialty and endangered the health of the population. In this category came all those who were convinced that Dentistry was a technical work that is not related to Medicine. To justify their point of view, the organizations of these dilettantes also sought the help of the officials, trying to divert doctors' efforts in their memoirs and calls, including addresses to the king [10].

Based on such a view, after the First World War the country was invaded by a lot of profiteers, dilettantes, extortionists, charlatans, illicit people who created real sanitary disasters, often causing the death of the patient. Dentistry in Romania was practiced even by the illiterates, thus creating a major national problem $[11,12]$. The education of the population and its protection from these parasites became a nearly impossible national mission, for many reasons, among which we could mention: the absence in Romania of a Superior Dentistry Department, the lack of dentists specialized in dentistry, the aggressive assault of the dilettantes on this sanitary sector where a particularly profitable land was found. Corruption had reached alarming levels among the state officials, making concessions to those unprofessional practitioners. Even in the Romanian Academy it was stated that Romania was under the "tyranny of mediocrity".

In all congresses organized by the General Association of Doctors of Dentistry, led by Prof. Bilaşcu, most of the time was consumed in attempts to find solutions to solve this problem [13]. As President of the aforementioned associations, Prof. Bilaşcu led a titanic struggle against those mentioned. No doubt, neither venality, nor the threats, nor the failures, nor the ignorance of some, nor the lack of conviction and fatigue of others, could discourage him $[14,15]$.

In order to achieve some results, Prof. Bilaşcu also used his position as parliamentarian [16]. In addition, he appealed to the support of famous personalities such as Emil Racoviţă and Jacob Iacobovici who, besides him, raised the issue not only with the Government but also with the Parliament of Romania [17,18].

The preemptive work and the sacrifice of Prof. Gheorghe Bilaşcu for the national good ended with his unpredictable death on July 22, 1926 [19]. At this unfortunate moment, he left behind an organized Higher Dentistry, a national specialized scientific journal, a dental health network under organization, a national professional association ("The National Association of Doctors in Dentistry") and a purification mechanism of Dentistry by those who abused it. However, he did not manage to cleanse completely the field, and therefore, this task was left for his followers.

\section{References}

1. Bologa V. Vorbire la înmormântarea Prof. Bilaşcu [Eulogy at Prof. Bilascu's funeral]. Revista Stomatologică. 1928;23:19-21.

2. Pascu O, Popescu H, Bârsu C. Şcoala Clujeană de Medicină şi Farmacie. Ctitorii faimei [The Romanian School of 
Medicine. The founders of fame]. 1919 - 1999. Cluj-Napoca: Editura Medicală Universitară „Iuliu Haţieganu”; 1999.

3. Marian F. Prof. Dr. Gheorghe Bilaşcu, fondatorul Învăţământului Stomatologic Românesc [Prof. Dr. Gheorghe Bilaşcu, the founder of Romanian dental education]. Pagini Medicale Bârlădene, septembrie 2001.

4. Rotaru Al, Petrovai I, Rotaru H. Professor Gheorghe Bilaşcu's contribution to the development of science and culture in Romania. Clujul Med. 2016;3,:443-447.

5. Bologa VL. Rememorări sentimentale [Sentimental recollections]. Bucureşti: Editura Didactică şi Pedagogică; 1985.

6. Ghibu O. Pe baricadele vieţii [On life's barricades]. ClujNapoca: Editura Dacia; 1981.

7. Dubala V. Dr. Bilaşcu. Revista „Zimbrul”, 1970, Liceul Bogdan Vodă, Vişeu de Sus.

8. Friedmann L. Expunere la Congresul Asociaţiei Doctorilor în Medicină Stomatologi din Cernăuți. [Presentation at the Congress of the Dental Surgeons' Association of Cernauti] Revista Stomatologică. 1923;9-10:172.

9. Bârsu C. The recognition of Gheorghe Bilașcu's contribution in the Romanian history of dentistry. Clujul Med. 2013;86:290-294.

10. Memoriu adresat domnilor deputaţi şi Excelenței Sale D-lui. N. Săveanu - Ministrul Sănătăţii Publice. [Memoir addressed to the deputies and his Excellence Mr. N. Saveanu, Minister of Public Health] Revista Dentară Română. 1925, V, $3,7$.

11. Niculescu DD. Lege pentru exerciţiul Dentisticei. Lege defectuoasă. Aplicare criminală. Sănătatea şi viaţa suferinzilor grav primejduite Law for exercising dentistry. Faulty law. Criminal application. The health and life of patients in serios jeopardy]. Bucureşti, Atelierele „Adevărul”, 1924.

12. Niculescu DD. Cuvântare la Congresul Asociaţiei Doctorilor în Medicină Stomatologi din Timişoara, 5 iulie 1924 [Presentation at the Congress of the Dental Surgeons' Association of Timisoara]. Revista Stomatologică. 1924, 8, 35.

13. Congresele Asociaţiei Doctorilor în Medicină Stomatologi din Bucureşti 1920, Cluj 1923, Timişoara 1924, Iași 1925 [Congresses of Dental Surgeons in...]. Revista Stomatologică, 1925.

14. Băbuţiu I. Amintiri despre Prof. Bilaşcu [Memories about Prof. Bilascu]. Revista Stomatologică, 1930, 319.

15. Marin F. Facultatea de Medicină şi Spitalele din Cluj (15001990) [The Faculty of Medicine and the hospitals in Cluj], Cluj-Napoca: Editura Casa Cărţii de Ştiinţă; 2004, 102.

16. Lechinţan V. Dicţionar. Oficialităţi de Stat Români din Transilvania 1368 - 1918 [Dictionary. State Officials from Transylvania]. Cluj-Napoca: Editura Argonaut; 2003, 53.

17. Procese Verbale ale Consiliului Profesoral al Facultăţii de Medicină şi Farmacie Cluj [Memos of the Professorial Council of the Faculty of Medicine and Pharmacy of Cluj]. Arhivele de Stat Cluj-Napoca, Fond 650, dosar (inv.) 43.

18. Iacobovici I. Panegiricul lui Gheorghe Bilaşcu [Gheorghe Bilascu's panegiric]. Revista Stomatologică. 1928, V, 2-3, 46.

19. 10 Ani de la moartea Prof. Bilaşcu [10 years from Prof. Bilascu's death]. Revista Stomatologică. 1936, p. 292. 